Voerman, B., Fischer, M., Visser, A., Garssen, B., Andel, G. van, Bensing, J.

Features of members of a prostate cancer patients' association.

Journal of Men's Health and Gender: 3, 2006, nr. 4, p. 379-389

\begin{tabular}{|l|l|}
\hline $\begin{array}{l}\text { Postprint } \\
\text { Version }\end{array}$ & 1.0 \\
\hline Journal website & http://www.sciencedirect.com/science/journal/15718913 \\
\hline Pubmed link & \\
\hline DOI & $\underline{10.1016 / j . j m h g .2006 .09 .007}$ \\
\hline
\end{tabular}

Bert Voerman, MA - Helen Dowling Institute, Centre for Psycho-oncology (HDI), Utrecht, The Netherlands

Maarten Fischer, MA - Helen Dowling Institute, Centre for Psycho-oncology (HDI), Utrecht, The Netherlands

Adriaan Visser, PhD - Helen Dowling Institute, Centre for Psycho-oncology (HDI), Utrecht, The Netherlands

Bert Garssen, PhD - Helen Dowling Institute, Centre for Psycho-oncology (HDI), Utrecht, The Netherlands

George van Andel, PhD - Onze Lieve Vrouwe Gasthuis (OLVG), Amsterdam, The Netherlands Jozien Bensing, PhD - National Institute for Health Services Research (NIVEL), Utrecht, The Netherlands

E-mail: b.voerman@hdi.nl

\title{
Features of members of a prostate cancer patients' association
}

\author{
BERT VOERMAN, MAARTEN FISCHER, ADRIAAN VISSER, BERT GARSSEN, GEORGE VAN ANDEL AND \\ JOZIEN BENSING
}

\begin{abstract}
Background: The objective of this study was to compare prostate cancer (PC) patients who are and who are not members of the Dutch prostate cancer patients' association (PCPA) with respect to demographic, medical and psychosocial characteristics.

Methods: Using a cross-sectional design, 88 non-members and 150 members of the PCPA were included.

Results: The results show that members are younger, have a higher socio-economic status and experience higher levels of distress. Furthermore, members are less content with the patient education and the psychosocial support available in hospital. Members also have a higher need to talk about problems and a more positive attitude towards participation in support groups.

Conclusion: It can be concluded that members of the patients' association differ from non-members. This has clinical and methodological relevance for further study among PC patients, as well as practical relevance for the policy of patients' associations.
\end{abstract}

\section{INTRODUCTION}

The incidence of cancer in the Netherlands was 69,000 cases in the year 2000. The prevalence of cancer patients in that same year was approximately 366,000 [1]. For many types of cancer, patients' associations have been founded. There are 24 registered patients' associations in the Netherlands, together accommodating 25,000 cancer sufferers. This implies that $7 \%$ of the cancer patients are members of a patients' association. In 1997 the prostate cancer patients' association (PCPA) was founded in the Netherlands; nearly 7000 new cases of prostate cancer (PC) are diagnosed each year [2]. In the year 2000, the prevalence of PC was 33,000 patients, while the PCPA had about 400 members $(1 \%)$, which is a much smaller number of patients than is found in other associations. 
There may be several reasons for joining a patients' association. Patients may have needs related to having cancer or may join a patients' association for information, support or activities [3].

Shortcomings in the professional healthcare available can also be a reason for becoming a member of a patients' association [4].

Survival rate also plays a role. Treatment of localised PC by surgery or radiation is effective in producing a good survival rate (51-95\% after 5 years) [5], but can also cause serious side effects [6]. Metastatic PC, hormonally treated, has a survival rate of $20 \%$ after 5 years [7]. Because of the good survival rate, men and their partners have to learn to live with the side effects of the treatment and/or the fear of recurrence. Patient organisations can help with this. Knowledge regarding the psychosocial problems of men with $\mathrm{PC}$ has grown in the last decade. Studies report the presence of anxiety $(8-$ $49 \%$ ), depression (0-48 \%), post-traumatic stress disorder (14\%) and feelings of isolation $(20 \%)[8,9]$. These may also be reasons for finding support in a patient organisation.

There are no studies available that compare the psychosocial problems between members and nonmembers of a patients' organisation. However, there are some studies comparing socio-demographic and psychosocial factors of those men joining a support group and those who do not. Support groups are often organised by patients' organisations [10]. Katz et al found that men who attend a PC support group had a higher income and a higher socio-economic status [11]. That study also reported better mental health among support group members. Another study found differences in coping style between men who did and who did not attend a support group. Men who attended a support group more often endorsed anxious preoccupation as a coping style [12]. Gray et al showed that men attended self-help groups in order to get information about PC [13]. The same held true for a study by Carlsson et al [3], who found that $53 \%$ of the members of a patients' association for men with PC wanted to use the patients' association for information and activities. This is consistent with another study that indicated a gap between the informational needs of patients and the actual information provided by health professionals [14]. There are also indications that social support needs are unmet by healthcare professionals [15]. These studies reflect the idea that support groups can facilitate adaptation to the problems related to PC. These studies, however, do not provide any knowledge of how far just membership of a patients' association might facilitate this adaptation. Both the decision to become a member of a patients' organisation and enrolling in a support group represent an attitude of taking a more active role in dealing with the disease.

Since there are no studies on the characteristics of members of a PCPA compared to non-members, it is important to gain knowledge on their possible differences for a number of reasons. There are a growing number of PC patients, making knowledge about this issue increasingly important. It is unknown why only a small number of PC patients are actively involved in their disease, as reflected by membership. Active involvement can be associated with better mental health so it would be interesting to motivate men to join the patients' association. Such a study could also provide information on the features of men who want or need extra support in coping with their disease and which psychosocial support is needed. Finally, from a methodological viewpoint, if there are differences between members and non-members, membership of a patients' association could be a confounder which would have to be taken into account in studies on psychosocial problems and quality of life of men with PC.

In the present study, members and non-members were compared with respect to socio-demographic variables (age, socio-economic and marital status), medical characteristics (treatment, disease stage, time since diagnosis), satisfaction with hospital care, psychosocial characteristics (quality of life, sexuality, joy in life, psychosocial problems/needs, worries about the level of prostate specific antigen (PSA), distress, coping strategies, social support, emotional regulation and spirituality), attitude, subjective norms and perceived possibilities towards participation in support groups.

\section{METHODS}

\section{Data collection}

This study is part of a larger research project assessing health-related quality of life, psychosocial problems and the need for psychosocial support in PC patients. This research project was approved by the medical ethical board of the Onze Lieve Vrouwe Gasthuis, Amsterdam, The Netherlands. For the recruitment of patients, leaflets providing information about the study and including a response card 
were used. Urologists in five hospitals handed out these leaflets. The leaflets were also mailed to all members of the Dutch PCPA. When an affirmative response was received, a questionnaire was mailed to the patient. Inclusion criteria for the study were having PC at any stage and speaking and reading Dutch to a sufficient level to understand the questionnaires. Exclusion criteria were having another type of cancer or a serious disease that impaired health related quality of life. These criteria were obtained from medical files and by patient's self-reports.

\section{Instruments}

Since this was the first large study in the Netherlands on health related quality of life and psychosocial problems in men with PC, an exploratory and descriptive approach was chosen. Therefore a wide variety of questionnaires was used to obtain detailed information about background characteristics, medical history, health-related quality of life, emotional well being, social support, psychosocial problems and the need for support in men with PC. An overview of the psychometric characteristics and the background to the measures applied is presented in Table 1.

\section{[ TABLE 1 ]}

The Prostate Specific Antigen (PSA) Knowledge and Worries scale is an instrument we constructed for measuring both knowledge and fears about PSA levels. The scale, of the Likert type, was constructed in consultation with an urologist (G.v.A.). Some examples of items are: What is your last measured PSA level (knowledge)? Do you have worries about your PSA level? (worries). Are you nervous when you get the result of your PSA test? (worries). The scale was pre-tested in an urology practice among 15 patients who were then interviewed afterwards regarding their understanding of the meaning of the items, which was adequate in all patients. The reliability of the worries scale is good ( $\alpha$ $=0.82$ ).

Complaints about care and information supply by hospitals were highlighted in a brief pilot study [15]. Therefore, questions on satisfaction with hospital care were included to obtain insight into the extent that patients were content with various aspects of the information supplied by physicians and nurses, as well as with the care received in hospital. Both questionnaires had good reliability $(\alpha=0.88$ and $\alpha=0.86$ ).

Quality of life was included since it is an important concept in psycho-oncological research. It was measured using the standardised European Organisation for Research and Treatment of Cancer (EORTC) questionnaire; reliabilities ranged between $\alpha=0.67$ and 0.90 . The module on prostatespecific quality of life issues in the EORTC questionnaire is still under development. It has a low reliability for problems related to hormonal treatment $(\alpha=0.37)$ and bowel problems $(\alpha=0.52)$. To construct a measure for sexual problems for this particular population, items from the EORTC prostate cancer module, from studies by Voogt et al [16] and van Andel et al [17] and newly constructed items were used. Together these formed a broad measure of general sexual dysfunction $(\alpha=0.76)$. In addition, a joy of life scale, part of a questionnaire developed and tested to assess adjustment to cancer, was included [18].

The Psychosocial Problems Inventory was based on a questionnaire developed by Osse et al [19]. It is an inventory of nine problems together with how much the patient feels the urge to talk about these problems and with whom. The items include the following problem areas: physical complaints, social contacts, financial situation, feelings and emotions, communication with medical staff, sexuality, micturation, daily activities and memory and concentration. This questionnaire was pre-tested as described above for the PSA worries scale.

The measurement of Determinants of Group Participation is based on the theory of planned behaviour [20]. The items were developed according to the guidelines for that theory. The concepts measured are attitude towards support group participation $(\alpha=0.75)$, social norms concerning support group participation $(\alpha=0.68)$ and self-efficacy, defined as the perceived possibilities for support group participation $(\alpha=0.61)$. This questionnaire was also pretested as described above for the PSA worries scale.

Distress was measured using the Profile of Mood States (POMS) [21]. Some scales from the EORTC quality of life questionnaire (EORTC QOL C30) overlap with the POMS and with the Social Support List. However, is was decided to include both scales in the study because the POMS measures more 
dimensions of emotional states and the Social Support List includes more information on social support than does the EORTC QOL C30 scales.

Since being diagnosed as having cancer is often seen as a traumatic event, the Impact of Events Scale (IES) section on symptoms of posttraumatic stress disorder was included [22]. The POMS and the IES are often used in clinical research and have good reliabilities $(\alpha=0.91$ and $\alpha=0.90$, respectively).

The Life Events scale [23] and the Daily Hassles scale [24] were both reduced to one item. This was done to lessen the questionnaire burden for the patients. Social support was measured using the Social Support Questionnaire [25], coping by the Utrecht Coping List [26] and emotional control and rationality was measured using the Emotional Control and Rationality scale [27]. These last three are original questionnaires with good reliabilities. A measurement instrument for spirituality was included because this concept is becoming increasingly important in research in psycho- oncology $[28,29]$. The 'transcendence' subscale was omitted from the Spirituality Assessment Scale [30], because of its low reliability in another study [31].

\section{Analyses}

Correlation coefficients were calculated to determine the degree of overlap between the emotional functioning scale and the social functioning scale of the EORTC QOL C30 on the one hand and the POMS total score and the Social Support questionnaire on the other.

In order to test statistically for differences between members and non-members, $\mathrm{Chi}^{2}$-tests, student $t$ tests and Mann-Whitney $U$ tests were used, depending on the measurement level and the distribution of the variables. The significance level was set at $\alpha=0.05$. When corrected for multiple testing however, an $\alpha$ value of 0.001 was needed to reach significance. In addition, a logistic regression analysis (which is most suitable in exploratory studies), using the stepwise backward method was carried out to identify the main factors related to membership of the patients' association [32]. In that analysis, correlations between the various applied constructs can be taken into account.

\section{RESULTS}

\section{Subjects}

From the leaflets handed out, 303 affirmative response cards were returned: 110 from the hospitals and 193 from the patients' association. Questionnaires were sent to all of these men and $103(94 \%)$ of the hospital-recruited men returned their questionnaires compared with 157 (81\%) of the patients' association members.

Of the men recruited in hospital, 14 were in fact members of the PCPA and so were added to the group of members in the database. Furthermore, 15 'hospital' men and 7 patients' association men were rejected because they did not meet the inclusion criteria or had too many missing values. In total, 238 questionnaires were eligible for this study, 88 from men recruited in hospitals or at educational meetings and 150 patients' association members.

\section{Background characteristics}

The background characteristics of the respondents are presented in Table 2. The average age of nonmembers is 71.2 years, whereas that of members is 65.9 years. Non-members have a lower score of 7.2 on the socio-economic status scale than members, who score 8.7 . The vast majority of all subjects (78\% and $84 \%$ ) are married. Prostate cancer had been diagnosed more than 2 years ago for $60 \%$ of non-members and $70 \%$ of members. For both groups almost one-third have metastasised PC. The most common treatments in non-members and members are radical prostatectomy (23\% and $29 \%)$, radiation therapy (21\% and $14 \%)$ and hormonal therapy $(25 \%$ and $24 \%)$, while combinations of operation or radiation and hormone therapy were given in $19 \%$ and $22 \%$ of the cases, respectively. Compared to non-members, patients' association members are younger and have a higher socioeconomic status. No significant differences were found for marital status, time since diagnosis, stage of the disease, type of treatment, comorbidity and PSA level. 


\section{[ TABLE 2 ]}

\section{Psychosocial characteristics}

Correlations between the emotional functioning subscale of the EORTC QOL C30 and the POMS total scale show a considerable overlap $(\mathrm{r}=-0.73, \mathrm{p}<0.01)$. The Social Support List score has a correlation of $r=-0.25$ with the social functioning scale of the EORTC QOL C30. The high correlation between the EORTC-C30 emotional functioning scale and the POMS total scale indicates that they probably, in part, measure the same construct. In the logistic regression analysis, these correlations will be taken into account. The results of the comparison of psychosocial factors between PCPA members and nonmembers are displayed in Table 3.

\section{[ TABLE 3 ]}

PCPA members have a greater knowledge of what PSA means and they also worry more about their PSA level. With respect to satisfaction with hospital care, members are less content with the information provided about PC and with their care in general, compared to non-members. Concerning quality of life, members have a lower score on emotional functioning compared to non-members. This is congruent with the higher distress scores found on the POMS for members and the lower joy in life scores found for non-members. Furthermore, a substantially higher score was found on the traumatic stress scale for members and with respect to coping, members have higher scores for problem avoidance. In addition, members show a lower score on emotional control, indicating they have fewer problems in showing their emotions compared to non-members.

Regarding psycho-social problems and needs, Table 3 shows that the number of problems relating to $\mathrm{PC}$ reported by patients is equal for members and non-members. However, the degree to which men want to talk about these problems is significantly higher among members. This is in acccordance with the finding that members have a more positive attitude towards support group participation than nonmembers. Members also report a higher sense of self-efficacy, which means they see themselves as more capable of attending group meetings. Finally, no significant difference was found between members and non-members in the percentage of men choosing to attend support groups, although there is a trend $(\mathrm{p}=0.09)$ for members to choose to attend.

\section{Logistic regression analysis}

The factors that differed significantly between members and non-members were used as predictor variables in a logistic regression to identify which factors were the most predictive for membership of the patients' association. Table 4 shows that six factors are associated with membership.

\section{[ TABLE 4 ]}

A higher socio-economic status and a lower age are associated with membership. Lower satisfaction with information about PC is also associated with membership. Clearly there is a constellation of distress factors associated with membership. Higher distress scores influence the odds of being a member in a positive way.

\section{CONCLUSION AND DISCUSSION}

To the best of our knowledge, this is the first study to compare members and non-members of a PCPA on a diversity of characteristics. Several interesting and coherent differences were found.

Dissatisfaction with the information provided by medical care givers as well as dissatisfaction with the care received in general, is associated with being a member of the patients' association. There is a strong need for information in these patients [33]. A difference can be made between medical information and information about the psycho-social consequences of PC. One study found that the urologist is a satisfactory source of medical information for most men [34]. Concerning information on experiential and psycho-social issues, another study pointed out that two thirds of both patients and physicians considered that the physician was not a good person to offer emotional support [10]. Information, on emotional and experiential support, as well as additional medical information can be very adequately obtained from fellow patients [35]. By attending a patients' association or a support group, men might find out that there is much more to know than the physician has explained, causing 
dissatisfaction retrospectively. The relatively younger men with a higher socio-economic status were more active information seekers. This has also been found in other studies outside the Netherlands $[11,36]$. This can be related to the finding that younger, more highly educated men wish to play a more active role in their treatment and the whole process of managing their disease and therefore need more information $[37,38]$.

The results concerning distress, coping and emotional regulation are also consistent. Members experience higher levels of distress, which is consistent with lower emotional control and poor coping strategies. Interestingly, the logistic regression analysis points out that three measures of emotional distress contribute significantly to the odds of being a member of the PCPA. This is surprising, given the fact that there is an overlap between these measures. Logistic regression takes into account shared variance, but still three different measures were kept in the equation as significant contributors. Studies have indicated that emotional support is less valued than information by PC patients [39]. However, our results show that lower emotional functioning and higher levels of distress are associated with membership of the patients' association. It can, therefore, be concluded that the PCPA governing body should emphasise the importance of sharing emotions in its policy statement and aim to develop programs or support groups that will target distress, especially traumatic stress, in addition to informational programs.

Regarding the methodology of this study, it can, indeed, be concluded that there is a considerable bias in the patients' association sample. Balderson et al found a similar result in their study of support group members, finding higher levels of distress than in other studies [40]. In future studies in PC patients, this is something to be aware of when sample-taking.

To compare our study with previous research, only studies concerning support groups for men with PC are available. Support groups are different because they can be regarded as an intervention more than can membership of a patients' association. Although we do not know why men became members of a patients' association, differences between members and non-members do give information about specific characteristics of members. These differences can not be explained by the decision to participate in support groups. At the time of this study, no groups had been organised, apart from one pilot study [41]. Also the percentage of men choosing a support group was equal in members and nonmembers.

This study has some limitations. Since the study design is cross-sectional, it is unknown whether men become members to alleviate their distress or whether membership causes distress. The latter seems, however, not very plausible, since other studies have highlighted the beneficial effects of attending support groups in men with PC [42]. This indicates that actively being involved in one's own illness process, perhaps also by being a member of a patients' association, can be beneficial in adapting to the experience of PC. Because of the many constructs involved in this study, one might argue that the results are based on multiple testing effects. However, when corrected for multiple testing using the Bonferroni procedure, most of the problem areas that had significant results between members and non-members remained significant. Another point of consideration is the length of the questionnaire. Having to answer many questions may lead to fatigue or loss of motivation, and this possibly influences the responses. The questionnaire included items on this matter and answers indicate that half the sample considered the questionnaire to be too long, while one third found it acceptable. Eighty percent found the questions to be not too difficult and only $7 \%$ considered the questions to be irrelevant. Instructions in the questionnaire booklet emphasised the need to take as much time as was necessary to fill out the questions. From this, it can be concluded that it is not likely that the number of questions produced a significant bias. However, only a limited number of concepts were found to be relevant for drawing conclusions from this study; these were satisfaction with the care and information from the hospital, emotional distress measures, psychosocial problems and needs, and attitude towards group participation. For future studies, this is an indication of which concepts can play a role and which do not in comparing different groups of PC patients.

The clinical relevance of this study is that knowledge has been gained on shortcomings in the professional health care for PC patients. The psychosocial areas of concern that need extra attention have been highlighted. One of the bottlenecks is information supply for the patient. The patients' association is one of the sources that can play a role in filling that gap by providing experiential information. One cause for concern is that traumatic stress was found to be higher among members. It 
Voerman, B., Fischer, M., Visser, A., Garssen, B., Andel, G. van, Bensing, J.

Features of members of a prostate cancer patients' association.

Journal of Men's Health and Gender: 3, 2006, nr. 4, p. 379-389

is recommended that urologists and patients' association organisers should be alert to traumatic stress symptoms and, if necessary, refer the patient for specialised psycho-social care.

The methodological relevance is that samples taken from a patients' association are biased.

Concerning future research, it is important to confirmthese results using a prospective design and to

elaborate knowledge of the features of men who become members of a PCPA.

\section{ACKNOWLEDGEMENTS}

This study was supported by a grant from the Dutch Cancer Foundation

\section{REFERENCES}

[1] Coebergh JWW, van de Poll-Franse LV, Alers JC, et al. Kanker in Nederland [Cancer in the Netherlands]. Amsterdam: Signaleringscommissie Kanker van KWF kankerbestrijding; 2004.

[2] Visser O, SieslingS, vanDijck JAAM. Incidence of Cancer in the Netherlands. Utrecht: Vereninging van integrale kankercentra; 2002.

[3] Carlsson C, Baigi A, Killander D, Larsson US. Motives for becoming and remaining member of patient associations: a study of 1,810 Swedish individuals with cancer associations. Support Care Cancer 2005;13:1035-43.

[4] Verklaar E. Strategisch gedrag van Kategorale Patiëntenorganisaties [Strategic behavior of catagorial patients organisations]. Thesis: Erasmus Universiteit, Rotterdam; 1991.

[5] Middleton RG, Thompson IM, Austenfeld MS, et al. Prostate Cancer Clinical Guidelines Panel Summary report on the management of clinically localized prostate cancer. The American Urological Association. J Urol 1995;154:2144-8.

[6] Litwin MS, Melmed GY, Nakazon T. Life after radical prostatectomy: a longitudinal study. J Urol 2001;166:587-92.

[7] Mettlin C. Changes in patterns of prostate cancer care in the United States: results of American College Surgeons Commission on Cancer Studies, 1974-1994. Prostate 1997; 32:221-6.

[8] Kornblith AB, Herr HW, Ofman US, Scher HI, Holland JC. Quality of life of patients with prostate cancer and their spouses. Cancer 1994;73:2791-802.

[9] Bisson JI, Chubb HL, Bennett S, Mason M, Jones D, Kynaston H. The prevalence and predictors of psychological distress in patients with early localized prostate cancer. BJU Int 2002;90:56-61.

[10] Weber BA, Roberts BL, McDougall GJ. Exploring the efficacy of support groups for men with prostate cancer. Geriatr Nurs 2000;23:250-3.

[11] Katz D, Koppie TM, Wu D, et al. Sociodemographic characteristics and health related quality of life in men attending pros- tate cancer support groups. J Urol 2002;168:2092-6.

[12] McGovern RJ, Heyman EN, Resnick MI. An examination of coping style and quality of life of cancer patients who attend a prostate cancer support group. J Psychosoc Oncol 2002;20:57-67.

[13] Gray R, Fitch M, Phillips C, Labrecque M, Fergus K. To tell or not to tell: patterns of disclosure among men with prostate cancer. Psychooncology 2000;9:273-82.

[14] Steginga SK, Occhipinti S, Dunn J, Gardiner RA, Heathcote P, Yaxley J. The supportive care needs of men with prostate cancer. Psychooncology 2001;10:66-75.

[15] Visser-Pol GE, van Klinken PC, Postma- Schuit FCE. Inventarisatie voorlichtings- en ondersteuningsbehoefte van patiënten met prostaatkanker en hun partners [Inventory of educational and supportive care needs of patients with prostate cancer and their partners]. Amsterdam: Intergraal Kankercentrum Amsterdam; 1997.

[16] Voogt E, Visser AP, van Andel G, Rovers P, Kurth KH, Goodkin K. Behoefte aan begeleiding en sociale steun bij mannen met prostaatkanker [The need of supportive care and social support of men with prostate cancer]. Tijdschr Soc Gezondheidsz 2001; 79:378-84.

[17] van Andel G, Visser AP, Hulshof MC, Horenblas S, Kurth KH. Health related quality of life and psycohosocial factors in patients scheduled for radical prostatectomy or external beam radiation therapy. BJU Int 2003;92:217-22.

[18] Bruin EJd, van Dijk M. HDI - Health and Disease Inventories, een meetinstrument voor aanpassing aan kanker. In: Handleiding [Health and Disease Inventories, a measurement instrument for adaptation to cancer. Manual]. Lisse: Swets en Zeitlinger; 1996.

[19] Osse B, de Vree B, Vernooij-Dassen M, Grol R, Schadee E. Vragenlijst problemen en behoeften

[Problems and needs questionnaire]. Nijmegen: KUN, Werkgroep Onderzoek Kwaliteit; 1999.

[20] Ajzen I. The theory of planned behavior. Organ Behav Hum Decis Process 1991; 50:179-211. 
Voerman, B., Fischer, M., Visser, A., Garssen, B., Andel, G. van, Bensing, J.

Features of members of a prostate cancer patients' association.

Journal of Men's Health and Gender: 3, 2006, nr. 4, p. 379-389

[21] Wald FDM, Mellenbergh GJ. De verkorte versie van de Nederlandstalige vertaling van de Profile of Mood States (POMS) [Short form of the Dutch translation of the POMS]. Ned Tijdschr Psychol 1990;45:86-90.

[22] Horowitz M, Wilner N, Alvarez W. Impact of Events Scale: a measure of subjective stress. Psychosom Med 1979;41:209-18.

[23] Sarason IG, Johnson JH, Siegel JM. Assessing the impact of life changes: development of the Life Experiences Survey. J Consult Clin Psychol 1978;46:932-46.

[24] Vingerhoets $A$, Jeninga AJ, Mengens LJ. Het meten van chronische en alledaagse stressoren: II Eerste onderzoekservaringen met de Alledaagse Problemen Lijst (APL) [Measurement of chronical and daily stressors: II first research experiences with the Daily Hassles List (APL)]. Gedrag en Gezondheid 1989;17:10-7.

[25] van Sonderen E. Sociale Steun Lijst - Interacties en Sociale Steun Lijst - Discrepanties. Een Handleiding [Social Support List - Interactions and Social Support List - Discrepancies. A Manual]. Groningen: Noordelijk Centrum voor Gezondheidsvraagstukken, Rijksuniversiteit Groningen; 1993.

[26] Schreurs PJG, van de Willige G, Brosschot JF, Tellegen B, Graus GMH. De utrechtse coping lijst. Omgaan met Problemen en Gebeurtenissen. Herziene handleiding [Utrecht Coping List. Coping with Problems and Events. Revised Manuel]. Lisse: Swets and Zeitlinger; 1993.

[27] Bleiker EMA, van de Ploeg HM, Hendriks JHCL, Leer JWH, Kleijn WC. Rationality, emotional expression and control: psychometric characteristics of a questionnaire for research in psychooncology. J Psychosom Res 1993;37:861-72.

[28] Brady M, Peterman A, Fitchett G, Mo M, Cella D. A case for including spirituality in quality of life measurement in oncology. Psychooncology 1999;8:417-28.

[29] McClain C, Rosenfeld B, Breitbart W. Effect of spiritual well-being on end-of-life despair in termally-ill cancer patients. Lancet 2003;361:1603-7.

[30] Howden JW. Development and Psychometric Characteristics of the Spirituality Assessment Scale. Thesis: Texas Women's University; 1995.

[31] Macdonald DA, LeClair L, Holland JC, Alter A, Friedman HL. A survey of measures of transpersonal constructs. J Transpersonal Psychol 1995;27:171-235.

[32] Menard S. Applied Logistic Regression Analysis. Thousand Oaks, CA: Sage; 1995, p. 7- 106.

[33] Boberg EW, Gustafson DH, Hawkins RP, et al. Assessing the unmet information, support and care delivery needs of men with prostate cancer. Patient Educ Couns 2003;49:233-42.

[34] Krol Y, van Dam FSAM, Horenblas S, Meinhardt W, Muller MJ. Informatiebehoefte van mannen met prostaatkanker en hun partners [Informational needs of men with prostate cancer and their partners]. Ned Tijdschr Geneeskd 2000;26:431-7.

[35] Gray RE, Fitch M, Davis C, Phillips C. Interviews with men with prostate cancer about their selfhelp group experience. J Palliative Care 1997;13:15-21.

[36] Grande GE, Myers RE, Sutton SR. How do patients who participate in cancer support groups differ from those who do not? Psychooncology 2006;15:321-34.

[37] Cassileth BR, Zupkis RV, Sutton-Smith K, March V. Information and participation preferences among cancer patients. Ann Intern Med 1980;92:832-6.

[38] Blanchard CG, Labrecque MS, Ruckdeschel JC, Blanchard EB. Information and decisionmaking preferences of hospitalised adult cancer patients. Soc Sci Med 1988;27: 1139-45.

[39] Gray R, Fitch M, Davis C, Phillips C. Breast cancer and prostate cancer self-help groups: reflections on differences. Psychooncology 1996;5:137-42.

[40] Balderson N, Towell T. The prevalence and predictors of psychological distress in men with prostate cancer who are seeking support. Br J Health Psychol 2003;8: 125-34.

[41] Riemens E, Visser AP, van de Jagt T, Vingerhoets A. Psychosociale begeleiding voor mannen met prostaatkanker en hun partners. Evaluatie van een voorlichtingsbijeenkomst en een gespreksgroep [Psycho-social support for men with prostate cancer and their partners. Evaluation of an educational meeting and a support group]. Utrecht: Helen Dowling Institute; 2000.

[42] Gre' goire I, Kalogeropoulos D, Corcos J. The effectiveness of a professionally led support group for men with prostate cancer. Urol Nurs 1997;17:58-66.

[43] Visser AP. De beleving van het verblijf in een algemeen ziekenhuis [The experience of the stay in a general hospital]. Assen: Van Gorcum; 1984.

[44] Aaronson NK, Ahmedzai S, Bergman B, Bullinger M, Cull AM, Duez MJ. The European Organisation for Research and Treatment of Cancer QLQ C30: a quality-of-life instrument for use in international clinical trials in oncology. J Natl Cancer Inst 1993; 85:365-76.

[45] Aaronson NK. 15011/30011: an international field study of the reliability and validity of the EORTC QLQ-C30 and a disease specific questionnaire module (The QLQ-PR25) for assessing the quality of 
Voerman, B., Fischer, M., Visser, A., Garssen, B., Andel, G. van, Bensing, J.

Features of members of a prostate cancer patients' association.

Journal of Men's Health and Gender: 3, 2006, nr. 4, p. 379-389

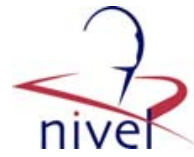

life of patients with prostate cancer. Brussels: European Organisation for Research and Treatment of Cancer; 2002.

[46] Derogatis LR, Kourlesis SM. An approach to evaluation of sexual problems in the cancer patient. CA Cancer J Clin 1981; 31:46-50.

[47] de Haes JCJM. Kwaliteit van leven van kankerpatiënten [Quality of life in cancer patients]. Amsterdam: Swets \& Zeitlinger; 1988.

\section{TABLES}

Table 1 Background and psychometric characteristics of the questionnaires used in this study

\begin{tabular}{|c|c|c|c|c|}
\hline Questionnaires & $\begin{array}{l}\text { Number } \\
\text { of items }\end{array}$ & Range & $\begin{array}{l}\text { Cronbach's } \\
\text { Alpha }\end{array}$ & Reference \\
\hline $\begin{array}{l}\text { 1. Prostate-specific antigen (PSA) worries scale } \\
\text { Knowledge of own PSA level } \\
\text { Knowledge of PSA in general } \\
\text { Worries about PSA }\end{array}$ & $\begin{array}{l}1 \\
3 \\
2\end{array}$ & $\begin{array}{l}0-997 \\
3-8 \\
2-8\end{array}$ & $\begin{array}{l}\text { n.a. } \\
0.36 \\
0.82\end{array}$ & This study \\
\hline $\begin{array}{l}\text { 2. Satisfaction with hospital care } \\
\text { Satisfaction with information about prostate cancer } \\
\text { Satisfaction with medical and emotional } \\
\text { support provided }\end{array}$ & $\begin{array}{l}4 \\
3\end{array}$ & $\begin{array}{l}4-20 \\
3-30\end{array}$ & $\begin{array}{l}0.88 \\
0.86\end{array}$ & $\begin{array}{l}\text { Visser [43] } \\
\text { Visser [43] }\end{array}$ \\
\hline $\begin{array}{l}\text { 3. Quality of life (EORTC-C30) } \\
\text { Physical functioning } \\
\text { Role functioning } \\
\text { Social functioning } \\
\text { Emotional functioning } \\
\text { Cognitive functioning } \\
\text { General health-related QOL }\end{array}$ & $\begin{array}{l}5 \\
2 \\
2 \\
4 \\
2 \\
2\end{array}$ & $\begin{array}{l}0-100 \\
0-100 \\
0-100 \\
0-100 \\
0-100 \\
0-100\end{array}$ & $\begin{array}{l}0.75 \\
0.85 \\
0.75 \\
0.86 \\
0.67 \\
0.90\end{array}$ & Aaronson et al. [44] \\
\hline
\end{tabular}


Voerman, B., Fischer, M., Visser, A., Garssen, B., Andel, G. van, Bensing, J.

Features of members of a prostate cancer patients' association.

Journal of Men's Health and Gender: 3, 2006, nr. 4, p. 379-389

Table 1 (Continued)

\begin{tabular}{lllll}
\hline Questionnaires & $\begin{array}{l}\text { Number } \\
\text { of items }\end{array}$ & Range & $\begin{array}{l}\text { Cronbach's } \\
\text { Alpha }\end{array}$ & Reference \\
\hline $\begin{array}{llll}\text { 4. Prostate cancer specific problems (EORTC-PR25) } \\
\text { Urological symptoms }\end{array}$ & 5 & $0-100$ & 0.77 & Aaronson [45] \\
Burden of urological symptoms & 3 & $0-100$ & 0.71 & \\
Bowel problems & 4 & $0-100$ & 0.52 & \\
Problems related to hormonal treatment & 6 & $0-100$ & 0.37 &
\end{tabular}

5. Sexuality

Sexual behaviour questionnaire (SBQ)

Total sexual dysfunction

Sexual problems (EORTC-PR 25)

6. Psychosocial Problems Inventory for prostate cancer

Number of problems

Need to talk about problems

based on Derogatis and

Attitude towards talking about prostate cancer

Attitude towards group participation

Perceived social norms

Personal efficacy

$9-9-39$

$2 \quad 0-100 \quad 0.81$

0.81

Kourlesis [46]

9

n.a.

Aaronson [45]

0-9

$1-3$

Osse et al. [19] adjusted

\section{Distress}

Profile of Mood States (POMS-short form)

Joy in life scale (Health and Disease inventory)

Impact of Events Scale (IES)

Life Events Scale

Daily Hassles scale

$\begin{array}{lll}1 & -2-2 & \text { n.a } \\ 10 & -10-10 & 0.75 \\ 8 & -8-8 & 0.68 \\ 3 & -2-2 & 0.61\end{array}$

Ajzen [20]

68

$32 \quad 0-4 \quad 0.91$

$13 \quad 0-100 \quad 0.87$

$15 \quad 15-60 \quad 0.90$

1 1-3 n.a.

1 1-3 n.a.

Wald and Mellenbergh [21] Bruin and van Dijk [18] Horowitz et al. [22] Based on Sarason et al. [23] Based on Vinherhoets et al. [24]

9. Social Support

Disease specific social support

$6 \quad 6-17 \quad 0.74 \quad$ De Haes [47]

Social Support Questionnaire Differences (SSL-D)

Daily affection

Emotional support

4-12

Von Sonderen [25]

Approval

Instrumental support

Companionship

Informational support

Total social support

$\begin{array}{lll}4 & 4-12 & 0.83 \\ 8 & 8-24 & 0.91 \\ 6 & 6-18 & 0.86 \\ 7 & 7-21 & 0.83 \\ 5 & 5-15 & 0.80 \\ 4 & 4-12 & 0.78 \\ 34 & 34-102 & 0.95\end{array}$

$\begin{array}{llll}\text { 10. Coping } & & & \text { Schreurs et al. [26] } \\ \text { Utrecht Coping List (UCL, short form) } & & & \\ \text { Problem focussed coping } & 5 & 5-20 & 0.83 \\ \text { Avoidance } & 4 & 4-16 & 0.77 \\ \text { Support seeking } & 5 & 5-20 & 0.72 \\ \begin{array}{l}\text { 11. Emotional Control and Rationality (ECR) } \\ \text { Rationality }\end{array} & 6 & & \text { Bleiker et al. [27] } \\ \text { Anti-emotionality } & 4 & 6-24 & 0.77 \\ \text { Understanding others } & 3 & 4-16 & 0.81 \\ \text { Emotional control } & 6 & 3-12 & 0.74 \\ \text { 12. Spirituality Assessment Scale (SAS) } & & 6-24 & 0.86 \\ \quad \text { Total score } & 22 & 22-88 & 0.90\end{array}$


Voerman, B., Fischer, M., Visser, A., Garssen, B., Andel, G. van, Bensing, J.

Features of members of a prostate cancer patients' association.

Journal of Men's Health and Gender: 3, 2006, nr. 4, p. 379-389

Table 2 Background characteristics of men who are and are not members of the Dutch prostate cancer patient association

\begin{tabular}{|c|c|c|c|}
\hline & $\begin{array}{l}\text { Non-members } \\
n=88\end{array}$ & $\begin{array}{l}\text { Members } \\
n=150\end{array}$ & Statistics \\
\hline \multicolumn{4}{|l|}{ 1. Background characteristics } \\
\hline \multicolumn{4}{|l|}{ Age } \\
\hline Mean (SD) & $71.2(6.7)$ & $65.9(8.3)$ & $t=5.46^{\star \star}$ \\
\hline Range & $56-86$ & $42-85$ & \\
\hline \multicolumn{4}{|l|}{ Socio-economic status } \\
\hline Mean (SD) & $7.2(2.2)$ & $8.7(2.1)$ & $t=-5.38^{* *}$ \\
\hline Range & $4-12$ & $4-12$ & \\
\hline \multicolumn{4}{|l|}{ Marital status $n(\%)$} \\
\hline Married & $69(78)$ & $126(84)$ & $\mathrm{Chi}^{2}=1.17$ \\
\hline Single & $19(22)$ & $24(16)$ & \\
\hline \multicolumn{4}{|l|}{ 2. Medical characteristics } \\
\hline \multicolumn{4}{|l|}{ Time since diagnosis $n(\%)$} \\
\hline$<1$ year & $17(20)$ & $16(11)$ & $\mathrm{Chi}^{2}=3.75$ \\
\hline$>1$ year $<2$ years & $15(18)$ & $28(19)$ & \\
\hline$\geq 2$ years & $52(62)$ & $102(70)$ & \\
\hline Missing & $4(4)$ & $4(2)$ & \\
\hline \multicolumn{4}{|l|}{ Metastasis n (\%) } \\
\hline No & $57(65)$ & $89(59)$ & $\mathrm{Chi}^{2}=1.83$ \\
\hline Yes & $26(30)$ & $45(30)$ & \\
\hline Not diagnosed & $5(6)$ & $16(11)$ & \\
\hline \multicolumn{4}{|l|}{ Treatment $n(\%)$} \\
\hline Radical prostatectomy (RP) & $20(23)$ & $43(29)$ & $\mathrm{Chi}^{2}=3.81$ \\
\hline Radiation therapy (RT) & $18(21)$ & $21(14)$ & \\
\hline Hormone therapy $(\mathrm{HT})$ & $22(25)$ & $36(24)$ & \\
\hline $\mathrm{RP} \& \mathrm{RT}$ & $4(5)$ & $10(7)$ & \\
\hline Intentionally curative $+\mathrm{HT}$ & $17(19)$ & $33(22)$ & \\
\hline No treatment/wait \& see & $7(8)$ & $7(7)$ & \\
\hline \multicolumn{4}{|l|}{ Number of other diseases } \\
\hline Mean (SD) & $0.8(0.8)$ & $0.6(0.8)$ & $t=1.56$ \\
\hline Range & $0-3$ & $0-3$ & \\
\hline \multicolumn{4}{|l|}{ Prostate specific antigen level } \\
\hline Mean (SD) & $13.4(48.8)$ & $20.1(91.2)$ & $t=-0.70$ \\
\hline Range & $0-400$ & $0-910$ & \\
\hline
\end{tabular}


Voerman, B., Fischer, M., Visser, A., Garssen, B., Andel, G. van, Bensing, J.

Features of members of a prostate cancer patients' association.

Journal of Men's Health and Gender: 3, 2006, nr. 4, p. 379-389

Table 3 Comparison of psychosocial factors in members and non-members of the prostate cancer patients' association

\begin{tabular}{llll}
\hline Measure & Non-members & Members & Statistics \\
& $n=88$ & $n=150$ & \\
& mean (SD) & mean (SD) & \\
\hline
\end{tabular}

1. PSA knowledge and worries scale

Knowledge of PSA

$\begin{array}{lll}2.6(1.4) & 3.5(1.4) & Z=-4.85^{\star \star \star} \\ 3.8(1.9) & 4.4(1.7) & Z=-2.90^{* *}\end{array}$

Worries about PSA level

$3.8(1.9)$

$11.3(3.9)$

$Z=3.26^{* * *}$

2. Satisfaction with hospital care
Satisfaction with information about

$12.9(3.7)$

$19.6(5.5)$

$Z=4.15^{\star \star \star}$

Satisfaction with medical and

$22.6(4.5)$

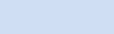

$Z=4.15^{* *+}$

3. Quality of life (EORTC-C30)

Physical functioning

$82.8(16.1)$
$85.6(21.6)$
$88.4(19.6)$
$85.1(19.1)$
$86.2(17.5)$
$78.9(16.0)$

$82.6(18.7)$

$Z=-0.53$

Role functioning

Social functioning

Emotional functioning

Cognitive functioning

$82.1(25.9)$

$Z=-0.66$

General health-related QOL

$78.9(16.0)$

$85.6(20.7)$

$24.4(17.8)$

$9.3(16.2)$

$4.8(9.0)$

$12.9(12.2)$

$77.8(20.7)$

$83.3(20.2)$

$Z=-1.18$

$Z=-3.06^{* *}$

$74.8(17.0)$

$Z=-0.91$

$Z=-1.71$

$22.2(16.4)$

$10.9(16.0)$

$5.9(9.8)$

$13.1(11.8)$

$Z=-0.85$

$Z=-1.93$

$Z=-1.01$

$Z=-0.24$

Prostate cancer specific problems (EORTC-PR 25)

Burden of urological symptoms

Problems related to hormonal treatment

5. Sexuality

Sexual Behaviour Questionnaire (SBQ)

Total sexual dysfunction

Sexual problems (EORTC-PR25)

$26.8(4.5)$

$22.2(22.6)$

\section{Distress}

Profile of Mood States

Joy in Life scale (HDI-A)

$-0.5(2.1)$

$59.8(10.3)$

$14.4(14.4)$

$1.7(0.7)$

Life Events scale

Daily hassles scale

$1.7(0.8)$

$16.2(3.7)$
$47.0(14.9)$

$27.1(4.6)$

$Z=-0.06$

$25.2(24.1)$

$Z=-0.81$

7. Social Support

Disease specific social support

Social Support Questionnaire

Differences (SSL-D)

Total social support $\begin{array}{ll}16.4(3.0) & Z=-0.23 \\ 48.5(13.5) & Z=-1.38\end{array}$

$\begin{array}{ll}0.4(2.9) & t=-2.71^{\star \star} \\ 56.6(9.9) & t=2.42^{*} \\ 22.3(14.6) & t=-3.96^{\star \star *} \\ 1.8(0.8) & Z=-1.47 \\ 1.8(0.9) & Z=-1.60\end{array}$


Voerman, B., Fischer, M., Visser, A., Garssen, B., Andel, G. van, Bensing, J.

Features of members of a prostate cancer patients' association.

Journal of Men's Health and Gender: 3, 2006, nr. 4, p. 379-389

Table 3 (Continued)

\begin{tabular}{|c|c|c|c|}
\hline Measure & $\begin{array}{l}\text { Non-members } \\
n=88 \\
\text { mean (SD) }\end{array}$ & $\begin{array}{l}\text { Members } \\
n=150 \\
\text { mean (SD) }\end{array}$ & Statistics \\
\hline \multicolumn{4}{|l|}{ 8. Coping } \\
\hline $\begin{array}{l}\text { Problem focussed coping } \\
\text { Avoidance } \\
\text { Emotional support seeking }\end{array}$ & $\begin{array}{l}12.2(3.6) \\
8.1(2.2) \\
9.5(2.7)\end{array}$ & $\begin{array}{l}13.1(3.0) \\
8.8(2.2) \\
10.0(2.2)\end{array}$ & $\begin{array}{l}Z=-1.91 \\
Z=-2.45^{*} \\
Z=-1.69\end{array}$ \\
\hline $\begin{array}{l}\text { 9. Emotional Control and Rationality } \\
\text { Emotional control } \\
\text { Rationality } \\
\text { Anti-emotionality } \\
\text { Understanding }\end{array}$ & $\begin{array}{l}17.5(3.9) \\
16.7(3.8) \\
9.4(2.8) \\
7.3(2.1)\end{array}$ & $\begin{array}{l}16.5(3.6) \\
16.9(3.0) \\
9.8(2.7) \\
7.5(1.9)\end{array}$ & $\begin{array}{l}Z=2.04^{*} \\
Z=-0.63 \\
Z=-0.81 \\
Z=-1.09\end{array}$ \\
\hline 10. Spirituality (SAS) total score & $62.7(11.0)$ & $62.1(9.9)$ & $Z=-0.85$ \\
\hline $\begin{array}{l}\text { 11. Psychosocial problems and needs } \\
\text { Number of problems } \\
\text { Need to talk about problems }\end{array}$ & $\begin{array}{l}4.1(2.3) \\
1.7(0.6)\end{array}$ & $\begin{array}{l}4.7(3.1) \\
2.2(0.5)\end{array}$ & $\begin{array}{l}t=-1.72 \\
t=-5.61^{* * *}\end{array}$ \\
\hline $\begin{array}{l}\text { 12. Determinants of group participation } \\
\text { Attitude towards group participation } \\
\text { Perceived social norms } \\
\text { Personal efficacy }\end{array}$ & $\begin{array}{l}0.72(2.5) \\
2.1(2.6) \\
0.7(1.0)\end{array}$ & $\begin{array}{l}2.5(2.5) \\
2.6(2.3) \\
1.0(0.8)\end{array}$ & $\begin{array}{l}t=-5.27^{* \star *} \\
t=-1.55 \\
t=-2.73^{* *}\end{array}$ \\
\hline $\begin{array}{l}\text { 13. Participated in groups } \\
\text { Yes } \\
\text { No }\end{array}$ & $\begin{array}{l}n \% \\
13(15) \\
75(85)\end{array}$ & $\begin{array}{l}n \% \\
34(23) \\
116(77)\end{array}$ & $\mathrm{Chi}^{2}=0.09$ \\
\hline
\end{tabular}

${ }^{*} p<0.05 ;{ }^{* \star} p<0.01 ;{ }^{* \star *} p<0.001$.

Table 4 Logistic regression analysis for factors related to membership of the patients' association

\begin{tabular}{lll}
\hline Factor & Odds ratio & $95 \% \mathrm{Cl}$ \\
\hline Socio-economic status & 1.28 & $1.08-1.53^{* *}$ \\
Distress (POMS) & 1.28 & $1.02-1.60^{*}$ \\
Impact of events scale & 1.05 & $1.02-1.09^{* *}$ \\
Emotional functioning & 1.03 & $1.00-1.07^{*}$ \\
Age & 0.91 & $0.86-0.96^{* *}$ \\
Satisfaction with information about prostate cancer & 0.86 & $0.78-0.94^{* *}$ \\
\hline
\end{tabular}

$N=238 ;$ POMS, Profile of Mood States; ${ }^{*} p<0.05 ;{ }^{* *} p<0.01$. 